\title{
THE UNSETTLED ISSUE FROM LEIDOS, INC. V. INDIANA PUBLIC RETIREMENT SYSTEM: SHOULD ITEM 303 Provide a Private Right of ACtion?
}

\author{
JON JACOBSON $^{*}$
}

\section{INTRODUCTION}

On June 18, 2018, the Supreme Court dismissed Leidos, Inc. v. Indiana Public Retirement System, a securities regulation case, because the parties settled shortly before the case was set to be heard. ${ }^{1}$ The crux of the case is the unsettled issue of the scope of liability under Section 10(b) of the Securities Exchange Act of 1934 and Securities and Exchange Commission (SEC) Rule 10b-5.2

In Leidos, numerous retirement funds filed a class action suit against Leidos, Inc. (formerly known as SAIC, Inc.), alleging a violation of Item 303 based on SAIC's failed CityTime project. ${ }^{3}$ The CityTime project was an automated timekeeping program for employees of New York City; the project unraveled in 2010, which caused Leidos to hire an outside law firm to conduct an internal investigation. ${ }^{4}$ As a result of this investigation, Leidos learned of a kickback scheme and improper timekeeping practices that overbilled New York City to make the project appear profitable (even under the scheme, profits were shortlived). ${ }^{5}$ Despite knowledge of this liability, Leidos did not disclose the findings of the investigation in its next Form 10-K (March 2011) and instead "touted its commitment to high standards of "ethical performance and integrity." Shortly thereafter, Leidos fired the head of the CityTime project and offered to repay the city $\$ 2.5$ million, but the city demanded $\$ 600$ million. ${ }^{7}$ Leidos ultimately agreed to reimburse the city approximately $\$ 500.4$ million and forfeit $\$ 40$ million in unpaid receivables. ${ }^{8}$ The basis for the action is primarily the material omission on the potential liability in Leidos's March 2011 Form 10-K. ${ }^{9}$

The Supreme Court granted certiorari to decide whether there is a duty to disclose under Item 303 of SEC Regulation S-K that is actionable under Section

* J.D. 2021, Indiana University Robert H. McKinney School of Law; B.S. 2017, Indiana University Kelley School of Business. I am grateful to everyone within the Indiana Law Review for providing helpful and constructive feedback, Professor Frank Sullivan and Professor Nicolas Georgakopoulos for their insight into securities law, and my family for all of their support.

1. Henry Klehm III et al., Supreme Court Dismisses Important Securities Case on Issue Likely to Arise Again, JD SuPRA (June 25, 2018), https://www.jdsupra.com/legalnews/supremecourt-dismisses-important-35436 [https://perma.cc/7MLE-FHKC].

2. Id.

3. Ind. Pub. Ret. Sys. v. SAIC, Inc., 818 F.3d 85, 91 (2d Cir. 2016).

4. Id. at 89 .

5. $I d$.

6. Id. (citation omitted).

7. Id. at 89-90.

8. Id. at 90 .

9. Id. at 91 . 
10(b) and Rule 10b-5. ${ }^{10}$ Item 303 requires public companies to make disclosures in their public filings such as quarterly and annual reports regarding "any known trends or uncertainties that have had or that are reasonably likely to have a material favorable or unfavorable impact on net sales or revenues or income from continuing operations." ${ }^{\prime 1}$ Public companies satisfy the requirements of Item 303 by creating a commentary on the uncertainties of the future known as the Management's Discussion and Analysis ("MD\&A"). ${ }^{12}$ Plaintiffs may file suit under Rule 10b-5, most frequently for fraudulent behavior or misrepresentation, through an implied private right of action. ${ }^{13}$ The crux of Leidos is whether this implied right of action should extend to Item $303 .{ }^{14}$

There remains a circuit split on this matter because the parties in Leidos settled; therefore, it is likely to reach the Supreme Court again. ${ }^{15}$ The Second Circuit is in direct conflict with the Third and Ninth Circuits on whether Item 303 establishes a duty to disclose that creates a private right of action. ${ }^{16}$ In 2000 , the Third Circuit held that Item 303 was not intended to create a private cause of action, while also acknowledging Item 303 is an "open issue." 17 In 2014, the Ninth Circuit held that Item 303 does not create a duty to disclose. ${ }^{18}$ This conflict emerged in 2015 when the Second Circuit asserted that it was "at odds" with the Ninth Circuit's interpretation in Stratte-McClure v. Stanley. ${ }^{19}$ The Second Circuit reached its decision in Leidos based on the reasoning it established in StratteMcClure. ${ }^{20}$

Before the facts of Leidos or the arguments are examined, this Note will provide an overview of terms frequently used in securities regulation which are essential to understanding the issue in Leidos. This Note will then examine the facts of Leidos and provide an explanation of the circuit split. Then, the argument for respondent and petitioner will be evaluated. The final section of this Note will provide an analysis arguing for a private right of action.

10. Klehm III et al., supra note 1.

11. 17 C.F.R. $§ 229.303$ (b)(2)(ii) (2020).

12. See generally Denise Voigt Crawford \& Dean Galaro, A Rule 10b-5 Private Right of Action for MD\&A Violations?, 43 SEC. REG. L.J., Fall 2015, at 1.

13. Klehm III et al., supra note 1.

14. Leidos Inc. v. Indiana Public Retirement System, SCOTUSblog (June 18, 2018), https://www.scotusblog.com/case-files/cases/leidos-inc-v-indiana-public-retirement-system/ [https://perma.cc/UEG9-VXJH].

15. Klehm III et al., supra note 1.

16. SCOTUSBlog, supra note 14.

17. Oran v. Stafford, 226 F.3d 275, 288 (3d Cir. 2000).

18. In re NVIDIA Corp. Sec. Litig., 768 F.3d 1046, 1054 (9th Cir. 2014).

19. Stratte-McClure v. Stanley, 776 F.3d 94, 103 (2d Cir. 2015).

20. Ind. Pub. Ret. Sys. v. SAIC, Inc., 818 F.3d 85, 94 (2d Cir. 2016). 


\section{OVERVIEW OF RELEVANT SECURITIES REGULATION TERMS, RULE 10B-5, AND ITEM 303}

\section{A. Relevant Terms}

First, what is a security in this context? A security is a fungible financial instrument which has some form of economic value. ${ }^{21}$ In Leidos, the security is the stock, owned by numerous investors, which represents ownership in Leidos, Inc., a publicly traded company. ${ }^{22}$ The statutory definition of a security is long and generally clear. ${ }^{23}$ The only common trouble is with the term "investment contract," which is beyond the scope of this Note. ${ }^{24}$

Two acts in the 1930s are largely responsible for the framework of securities regulation that remains in place to this day. ${ }^{25}$ First was the Securities Act of 1933 (the "Securities Act"). The drafting and legislating of the Securities Act quickly followed the 1929 stock market crash. ${ }^{26}$ The Act regulates securities by requiring disclosure of important financial information and provides the means for the SEC "to pass upon the merits of securities offerings and to prevent unworthy offerings." ${ }^{27}$ The idea that disclosure was the best method of regulation is best exemplified by Supreme Court Justice Louis Brandeis: "Sunlight is said to be the best of disinfectants; electric light the most efficient policeman." 28

The second of these acts was the Securities Exchange Act of 1934 (the "Exchange Act"). The Exchange Act was legislated to regulate securities on the secondary market to ensure the veracity of financial information and minimize fraud, material omissions, and misrepresentation. ${ }^{29}$ Furthermore, the Exchange Act sanctioned the formation of the SEC and empowered the Commission to regulate the securities industry, which includes prohibiting fraud and misrepresentation. ${ }^{30}$

One way the SEC regulates the securities market is through monitoring the key financial and business information of public companies. ${ }^{31}$ Public companies are required to file certain financial information and documents with the SEC;

21. Will Kenton, Security, InVESTOPEDIA, https://www.investopedia.com/terms/s/security.asp (last updated Mar. 20, 2021) [https://perma.cc/FU9H-QLW4].

22. SAIC, Inc., 818 F.3d at 85 .

23. See 15 U.S.C. $\S 77 \mathrm{~b}(\mathrm{a})(1)(2020)$.

24. See Larry D. Soderquist \& Theresa A. Gabaldon, Securities Regulation 128 (Robert C. Clark et al. eds., 8th ed. 2014).

25. Id. at 3 .

26. Id.

27. $I d$.

28. Louis D. Brandeis, Other People's Money and How the Bankers Use It 92 (1914).

29. See Soderquist \& GABALDON, supra note 24 , at 10.

30. Id.

31. Id. at 4-5; see U.S. SEC. \& ExChANGE COMmission, https://www.sec.gov (last visited Nov. 11, 2020) [https://perma.cc/28MT-358M]. 
these documents include Form 10-K (filed annually) and Form 10-Q (filed quarterly). ${ }^{32}$ Form $10-\mathrm{K}$ presents an extensive overview of a company's financial and business information and must include audited financial statements; the key information is generally packaged with the annual report a company sends out to its shareholders before an annual meeting. ${ }^{33}$ Form $10-\mathrm{Q}$ is similar to Form $10-\mathrm{K}$ except that the financial statements within Form 10-Q are generally unaudited. ${ }^{34}$ In addition to these forms, public companies must report certain material events through Form 8-K. ${ }^{35}$ Generally, companies have four days to file Form 8-K after the material event takes place. ${ }^{36}$ The instructions on Form 8 -K provide for the types of events that prompt the duty to file Form $8-\mathrm{K}$, including entry or termination of a material definitive agreement, completion of acquisition, and unregistered sales of equity securities. ${ }^{37}$

A company must follow Regulation S-K in order to complete forms and filings. The reporting and disclosure requirements of the Securities Act are included in Regulation S-K. ${ }^{38}$ Regulation S-K's different requirements are referred to as items. ${ }^{39}$ For example, Item 101 requires a description of the business and Item 303 requires the inclusion of the MD\&A.

The MD\&A is a section included in a public company's Form 10-K or Form $10-\mathrm{Q}{ }^{40}$ This section includes the thoughts and opinions of the company's executives and leadership, analyzes the company's performance, and discusses future plans and risks; the MD\&A must be completed in narrative form. ${ }^{41}$ In the Commission's words, the objectives of the MD\&A are:

a. To provide a narrative explanation of a company's financial statements that enables investors to see the company through the eyes of management;

b. To enhance the overall financial disclosure and provide the context within which financial information should be analyzed; and

32. Soderquist \& GABALDON, supra note 24 , at 6 .

33. Form 10-K, INVESTOR.GOV, https://www.investor.gov/introduction-investing/investingbasics/glossary/form-10-k (last visited Nov. 11, 2020) [https://perma.cc/LMT8-QNYF]; see also How to Read a 10-K, U.S. SEC. \& ExChAnge COMmission, https:/www.sec.gov/fastanswers/answersreada10khtm.html (last modified July 1, 2011) [https://perma.cc/7SYK-N5HQ].

34. Form 10-Q, InVESTOR.GOV, https://www.investor.gov/introduction-investing/investingbasics/glossary/form-10-q (last visited Nov. 11, 2020) [https://perma.cc/8KYJ-FZ9S].

35. Form 8-K, U.S. SEC. \& EXCHANGE COMMISSION, https://www.sec.gov/fastanswers/answersform8khtm.html (last visited Nov. 22, 2020) [https://perma.cc/VH4V-KPQL].

36. $I d$.

37. Id.

38. SODERQUiST \& GABALDON, supra note 24 , at 13 n.2.

39. $I d$.

40. See generally Marshall Hargrave, Management Discussion and Analysis - MD\&A, INVESTOPEDIA, https://www.investopedia.com/terms/m/mdanalysis.asp (last updated Sept. 30, 2020) [https://perma.cc/A35Q-Q896].

41. Id. 
c. To provide information about the quality of, and potential variability of, a company's earnings and cash flow so that investors can ascertain the likelihood that past performance is indicative of future performance. ${ }^{42}$

The MD\&A should not include boilerplate language and should instead be specific to the company's circumstances. ${ }^{43}$ The specific requirements are laid out in Item $303,{ }^{44}$ which will be examined later in this Note.

\section{B. Rule 10b-5}

The SEC drafted Rule 10b-5 to provide an anti-fraud rule for the purchase of securities. ${ }^{45}$ The rule borrows language from Section 10(b) of the Exchange Act, ${ }^{46}$ and reads:

\section{\$240.10b-5 Employment of manipulative and deceptive devices.}

It shall be unlawful for any person, directly or indirectly, by the use of any means or instrumentality of interstate commerce, or of the mails or of any facility of any national securities exchange,

(a) To employ any device, scheme, or artifice to defraud,

(b) To make any untrue statement of a material fact or to omit to state a material fact necessary in order to make the statements made, in the light of the circumstances under which they were made, not misleading, or

(c) To engage in any act, practice, or course of business which operates or would operate as a fraud or deceit upon any person, in connection with the purchase or sale of any security. ${ }^{47}$

For the purposes of this Note, section (b) of the rule is most relevant: it is unlawful to omit a material fact necessary in order to make statements made not misleading, ${ }^{48}$ which is the issue in Leidos. Shortly after Rule 10b-5's inception, a district court observed that Rule 10b-5 provides an implied private right of action. ${ }^{49}$ This implied private right of action is invaluable as it allows investors to get corporations into court. ${ }^{50}$ If this implied private right of action did not exist, numerous investors would have little to no recourse if a corporation commits

42. Topic 9-Management's Discussion and Analysis of Financial Position and Results of Operations (MD\&A), U.S. SEC. \& EXCHANGE COMMISSION, https://www.sec.gov/corpfin/cfmanual/topic-9 (last modified May 11, 2018) [https://perma.cc/T3TN-YUA9].

43. $I d$.

44. Id.

45. Soderquist \& GABALDON, supra note 24 , at 407.

46. $I d$.

47. 17 C.F.R. $\S 240.10 b-5$ (2020).

48. See id.

49. SodERquist \& GABALDON, supra note 24 , at 408 .

50. See id. 
fraud and causes its investors financial harm. ${ }^{51}$ Another significant case in the development of Rule 10b-5 law is Basic Inc. v. Levinson. ${ }^{52}$ In addition to establishing the fraud-on-the-market theory, Basic also created the test to determine whether a forward-looking statement is required ${ }^{53}$ :

In Basic Inc. v. Levinson, the Supreme Court concluded that, in securities fraud cases under Section 10(b) and Rule 10b-5, the materiality of an allegedly required forward-looking disclosure is determined by "a balancing of both the indicated probability that the event will occur and the anticipated magnitude of the event in light of the totality of the company activity., 54

The circuit courts frequently cite or refer to the Basic court in determining whether Item 303 provides a private right of action under Rule 10b-5. ${ }^{55}$

\section{Item 303}

Item 303 of Regulation S-K, Management's Discussion and Analysis of Financial Condition and Results of Operations, outlines the required portions of the MD\&A section. ${ }^{56}$ The overriding requirement of Item 303 according to the SEC is to "provide readers information 'necessary to an understanding of [a company's] financial condition, changes in financial condition and results of operations." " ${ }^{57}$ Many gray areas exist as to whether certain information has to be provided and when disclosure becomes mandatory. ${ }^{58}$ The SEC provides that disclosure is mandatory where there is a known trend or uncertainty that is "reasonably likely to have a material effect on [the registrant's] financial condition or operating performance." 59 The SEC's two-part test for a duty to report under Item 303 for a known trend is:

(1) Is the known trend . . . likely to come to fruition? If management determines that it is not reasonably likely to occur, no disclosure is required.

(2) If management cannot make that determination, it must evaluate

51. Id.

52. See Basic Inc. v. Levinson, 485 U.S. 224, 238 (1988).

53. See id.

54. Stratte-McClure v. Stanley, 776 F.3d 94, 102-03 (2d Cir. 2015) (emphasis in original) (quoting Basic, 485 U.S. at 238).

55. See id.; see also In re NVIDIA Corp. Sec. Litig., 768 F.3d 1046 (9th Cir. 2014).

56. 17 C.F.R. $\S 229.303$ (2020).

57. Commission Guidance Regarding Management's Discussion and Analysis of Financial Condition and Results of Operations, Securities Act Release No. 8350, Exchange Act Release No. 48,960, 68 Fed. Reg. 75,056, 75,056 (Dec. 29, 2003) (quoting 17 C.F.R. $\S 229.303$ (a)).

58. See Soderquist \& Gabaldon, supra note 24.

59. Commission Guidance Regarding Management's Discussion and Analysis of Financial Condition and Results of Operations, 68 Fed. Reg. at 75,057. 
objectively the consequences of the known trend ... on the assumption that it will come to fruition. Disclosure is then required unless management determines that a material effect on the registrant's financial condition or results of operations is not reasonably likely to occur. ${ }^{60}$

The SEC's two-part test highlights that any known trend which is likely to occur needs to be disclosed unless management finds that it will not have a material effect on the company's financials.$^{61}$ By placing the onus on management to find there is no financial impact, the SEC promotes the disclosure of known trends to the company's investors.

\section{LEIDOS FACTS AND INCONSISTENCY IN THE FEDERAL CIRCUITS}

\section{A. Leidos Procedural History}

Lead plaintiffs Indiana Public Retirement System ("INPRS"), Indiana State Teachers' Retirement Fund, and Indiana Public Employees' Retirement Fund (on behalf of themselves and other similarly situated investors) brought a securities fraud class action claim against Leidos, Inc. ${ }^{62}$ This claim was commenced pursuant to Section 10(b) and Section 20(a) of the Exchange Act, and SEC Rule 10b-5. ${ }^{63}$ INPRS alleged that Leidos made numerous false statements and omissions, which the District Court divided into four categories-statements regarding: (1) conformity to Generally Accepted Accounting Principles ("GAAP"), (2) Leidos's disclosure and internal controls, (3) Leidos's commitment to ethics and integrity, and (4) the CityTime Project. ${ }^{64}$ The District Court ultimately decided with Leidos as to all claims. ${ }^{65}$

Plaintiffs appealed, which resulted in the Second Circuit addressing four issues:

(1) [Leidos's] alleged failure to comply with [GAAP] by failing to disclose appropriate loss contingencies associated with the CityTime project . . .; (2) [Leidos's] alleged failure to disclose a known trend or uncertainty reasonably expected to have a material impact on its financial condition, in violation of Item 303 . . ; (3) [Leidos's] scienter; and (4).

.. [Leidos's] allegedly misleading statements regarding its commitment

60. Management's Discussion and Analysis of Financial Condition and Results of Operations; Certain Investment Company Disclosures, Securities Act Release No. 6835, Exchange Act Release No. 26,831, Investment Company Act Release No. 16,961, 54 Fed. Reg. 22,427, 22,430 (May 24, 1989).

61. Id.

62. Ind. Pub. Ret. Sys. v. SAIC, Inc., 818 F.3d 85, 88 (2d Cir. 2016).

63. Id.

64. Id. at 91 .

65. Id. at 91-92. 
to ethics and integrity contained in its 2011 Annual Report to shareholders. ${ }^{66}$

The Second Circuit vacated the judgment of the District Court with respect to the GAAP and Item 303 claims and affirmed the judgment of the District Court with respect to the other claims. ${ }^{67}$ Leidos appealed, and the Supreme Court granted certiorari. ${ }^{68}$ The Supreme Court dismissed the case after the parties settled. ${ }^{69}$

\section{B. Important Leidos Facts}

Plaintiffs' claim arises from an overbilling scheme involving a web-based employee time-keeping project known as CityTime. ${ }^{70}$ In 2000, Leidos won the bid to become the government contractor for the project with New York City. ${ }^{71}$ Leidos anticipated that numerous projects from other cities and municipalities would arise if CityTime was largely successful and thus "kept a close eye on the project's progress." ${ }^{72}$

In 2002, Leidos hired Gerald Denault as Deputy Program Manger to oversee CityTime.$^{73}$ Denault brought in Technodyne, a relatively unknown firm, to be the sole source contractor, but the addition of Technodyne led to "an elaborate kickback scheme in which Technodyne illegally paid Denault and [another highlevel employee] for each hour a Technodyne consultant or subcontractor worked on CityTime." "74 This scheme persuaded Denault to hire far more Technodyne employees than required and to increase billable hours and rates. ${ }^{75}$

Because of the scheme, Leidos initially experienced losses for CityTime. ${ }^{76}$ Denault renegotiated the contract so that any cost overruns would now transfer to New York City. ${ }^{77}$ Through 2011, Leidos billed \$635 million; \$63 million was the amount initially budgeted. ${ }^{78}$ The kickback scheme under CityTime had started to fall apart by the end of $2010 .^{79}$ Leidos hired an outside law firm to conduct an

66. Id. at 88 (scienter here means intent or knowledge of wrongdoing).

67. Id.

68. Leidos, Inc. v. Ind. Pub. Ret. Sys., 137 S. Ct. 1395, 1396 (2017).

69. Leidos, Inc. v. Ind. Pub. Ret. Sys., 138 S. Ct. 2670 (2018); Andrew Chung, U.S. Top Court Drops Leidos Contracting Fraud Case After Settlement, ReUTERs (Oct. 17, 2017), https:/www.reuters.com/article/us-usa-court-securities/u-s-top-court-drops-leidos-contracting-fraudcase-after-settlement-idUSKBN1CM2C0 [https://perma.cc/3HZV-9HCS].

70. SAIC, Inc., 818 F.3d at 89.

71. Id

72. Id.

73. Id.

74. $I d$

75. $I d$.

76. Id.

77. Id.

78. Id.

79. Id. 
internal investigation and placed Denault on administrative leave. ${ }^{80}$ New York City Mayor Michael Bloomberg announced he was reviewing whether to seek recovery from Leidos ${ }^{81}$ Leidos learned of the improper timekeeping practices on March 9, 2011. ${ }^{82}$

Leidos filed a Form 10-K on March 25, 2011, that did not disclose any potential liability connected to CityTime or any mention of Mayor Bloomberg's announcement. ${ }^{83}$ In May 2011, Denault was fired, and Leidos offered to pay New York City \$2.5 million. ${ }^{84}$ Leidos filed a Form 8-K on June 2, 2011, where it disclosed the following: (1) "the United States Attorney's Office for the Southern District of New York ... and the New York City Department of Investigation . .. were conducting a joint criminal investigation into the CityTime contract"; (2) Leidos had billed a total of \$635 million for CityTime; (3) Denault was arrested for fraud; and (4) Leidos had "offered to refund . . . the \$2.5 million that Denault billed as part of the kickback scheme." ${ }^{\circ 5}$

Leidos filed a second Form 8-K on July 1, 2011, which contained a letter from New York City formally demanding that Leidos return $\$ 600$ million. ${ }^{86} \mathrm{On}$ August 31, 2011, Leidos "issued a press release announcing losses" due to the ending of CityTime and " "probable' restitution" to New York City. ${ }^{87}$ In March 2012, Leidos returned \$500.4 million to New York City and forfeited \$40 million in accounts receivable and issued a Statement of Responsibility. ${ }^{88}$ Leidos's stock price fell considerably during this time. ${ }^{89}$

\section{Examining the Circuit Split}

On September 7, 2000, the Third Circuit decided Oran v. Stafford in an opinion written by Justice Samuel Alito. ${ }^{90}$ The plaintiffs brought a securities class action claim against American Home Products Corporation ("AHP") and several of its directors and officers alleging that the corporation "made material misrepresentations and omissions" about the safety of two withdrawn prescription weight loss drugs. ${ }^{91}$ Starting in 1994 and continuing into the next couple of years, cardiologists across Europe alerted AHP to at least thirty-one different cases of
80. Id.
81. Id.
82. Id.
83. Id.
84. Id.
85. Id. at $89-90$.
86. Id. at 90 .
87. Id.
88. Id.
89. Id.
90. Oran v. Stafford, 226 F.3d 275 (3d Cir. 2000).
91. Id. at 279 . 
heart-valve abnormalities stemming from the weight loss drugs. ${ }^{92}$ The court noted that AHP only informed the FDA about eight of these cases and did not disclose any of this information to the public until July $1997 .^{93}$ These events led to a decrease in share price, i.e., plaintiff's financial loss. ${ }^{94}$

The court held that violations of Item 303 do not "create an independent cause of action for private plaintiffs." language of the regulation nor the SEC's interpretative releases construing it suggest that it was intended to establish a private cause of action, and courts construing the provision have unanimously held that it does not do so." 96

The court also explained that the Basic materiality standards for Rule 10b-5 and Item 303 "differ significantly [so that] the demonstration of a violation of the disclosure requirements of Item 303 does not lead inevitably to the conclusion that such disclosure would be required under Rule 10b-5. Such a duty to disclose must be separately shown." ${ }^{.97}$ The court highlighted language from the SEC in reaching its conclusion: "the probability/magnitude test for materiality approved by the Supreme Court in Basic . . . is inapposite to Item 303 disclosure." 98 The court then asserted that Item 303's disclosure obligations continue beyond the requirements of Rule $10 \mathrm{~b}-5 .{ }^{99}$ The court concluded by holding that "a violation of [Item 303's] reporting requirements does not automatically give rise to a material omission under Rule 10b-5." 100

On October 2, 2014, the Ninth Circuit decided In re NVIDIA Corporation Securities Litigation. ${ }^{101}$ Plaintiffs brought a claim of securities fraud alleging defendant corporation made disclosures more than a year after it should have informed investors about certain product defects. ${ }^{102}$ In 2006, NVIDIA began experiencing significant issues with two of its products. ${ }^{103}$ However, NVIDIA did not disclose any of this information in a Form with the SEC until May 22, $2008 .{ }^{104}$ One month later, in a Form 8-K, NVIDIA disclosed it would spend $\$ 150$ to $\$ 200$ million in order to resolve the product defects; NVIDIA's share price declined thirty-one percent following the disclosure. ${ }^{105}$

The court held that Item 303's disclosure duty is not actionable under Section

92. Id.

93. Id. at 279-80.

94. Id. at 280 .

95. Id. at 287 (quoting In re Burlington Coat Factory Sec. Litig., 114 F.3d 1410, 1419 n.7 (3d

Cir. 1997)).

96. Id.

97. Id. at 288 (internal citations and quotation marks omitted).

98. Id. (citations omitted).

99. Id.

100. Id.

101. In re NVIDIA Corp. Sec. Litig., 768 F.3d 1046 (9th Cir. 2014).

102. Id. at 1048 .

103. Id. at 1049 .

104. Id. at 1050 .

105. Id. at 1050-51. 
10(b) and Rule 10b-5. ${ }^{106}$ The court highlighted that it has "strongly suggested that a violation of Item 303 cannot be used to show a violation of Section 10(b) and Rule 10b-5." ${ }^{\prime 107}$ This cast aside plaintiffs' assertion that Item 303 provides a duty to disclose, and that failure to disclose is deemed misleading for the purposes of Rule 10b-5. ${ }^{108}$ Furthermore, the court explained that for purposes of Rule 10b-5, material information does not need to be disclosed unless its omission would cause other disclosed information to be misleading. ${ }^{109}$ In reaching its decision, the court emphasized it was "persuaded" by the Third Circuit's decision in Oran. ${ }^{110}$

On January 12, 2015, the Second Circuit decided Stratte-McClure v. Stanley. ${ }^{111}$ Plaintiff investors brought a securities fraud class action alleging defendant corporation and several officers made "material misstatements and omissions" to disguise losses in the subprime mortgage market near the time of the Great Recession. ${ }^{112}$ Morgan Stanley lost several billion dollars because it underestimated the extent of the subprime mortgage crisis. ${ }^{113}$ Plaintiffs alleged Morgan Stanley hid these losses for several months. ${ }^{114}$ Plaintiffs claimed they experienced substantial financial loss after the public disclosure of the truth because this disclosure led to a significant drop of the stock price. ${ }^{15}$

The court began its analysis with: "Silence, absent a duty to disclose, is not misleading under Rule 10b-5." 116 The court recognized that Item 303 does provide an affirmative duty to disclose, and several circuits hold that Item 303 is actionable under Sections 11 and 12(a)(2) of the Securities Act. ${ }^{117}$ Because the Item 303 disclosures are mandatory, "a reasonable investor would interpret the[ir] absence . . . to imply the nonexistence of "known trends or uncertainties." "118 Contrary to the two prior cases, the court concluded that "a failure to make a required disclosure under Item $303 \ldots$ in an [SEC] filing" can be the basis for a claim. ${ }^{19}$ The court reasoned:

That is, a plaintiff must first allege that the defendant failed to comply with Item 303 in a 10-Q or other filing. Such a showing establishes that the defendant had a duty to disclose. A plaintiff must then allege that the

106. Id. at 1054 .

107. Id.

108. Id.

109. Id. at 1055-56.

110. Id. at 1054; see Oran v. Stafford, 226 F.3d 275, 287-88 (3d Cir. 2000).

111. Stratte-McClure v. Stanley, 776 F.3d 94 (2d Cir. 2015).

112. Id. at 96 .

113. Id. at 97 .

114. Id. at 98 .

115. Id. at 96 .

116. Id. at 100-01 (quoting Basic Inc. v. Levinson, 485 U.S. 224, 239 n.17 (1988)).

117. $I d$. at 101 .

118. Id. at 102 (quoting 17 C.F.R. § 229.303(a)(3)(ii) (2020)).

119. Id. at 107. 
omitted information was material under Basic's probability/magnitude test, because 10b-5 only makes unlawful an omission of "material information" that is "necessary to make . . . statements made" . . . "not misleading." $" 120$

Therefore, a violation of Item 303's disclosure can result in a claim under Section 10(b) and Rule 10b-5, if the materiality test in Basic is satisfied. ${ }^{121}$

Recall the decision in Basic, which requires a forward-looking statement. ${ }^{122}$ The decision In re NVIDIA Corp. noted, "Management's duty to disclose under Item 303 is much broader than what is required under the standard pronounced in Basic." "23 Because of this, the court held that Item 303's disclosure duty is not actionable, relying on the opinion in Oran v. Stafford. ${ }^{124}$ The Stratte-McClure court stated that the Ninth Circuit misunderstood Oran, and that is the reason the courts are in conflict. ${ }^{125}$ The Second Circuit contends that "Oran actually suggested . . . a violation of Item 303 could give rise to a material $10 \mathrm{~b}-5$ omission." ${ }^{126}$ Regardless of the Third Circuit's stance, the Second and Ninth Circuits are in conflict. ${ }^{127}$

\section{The Potential CONSEQUENCES OF A SuPREME COURT DeCision}

This section examines the arguments for both parties in the case. This includes claims from amicus briefs as well as the parties' briefs.

\section{A. Argument for Respondents}

Courts have recognized that private actions are a "necessary supplement" to the enforcement of securities regulation. ${ }^{128}$ The Supreme Court has stated, "The SEC enforcement program and the availability of private rights of action together provide a means for defrauded investors to recover damages and a powerful deterrent against violations of the securities laws." ${ }^{129}$ In Tellabs, Inc. v. Makor Issues \& Rights, Ltd., the Supreme Court held that " "private securities litigation [i]s an indispensable tool with which defrauded investors can recover their

120. Id. at 103 (quoting Matrixx Initiatives, Inc. v. Siracusano, 563 U.S. 27, 36 (2011)).

121. Id.

122. See Basic Inc. v. Levinson, 485 U.S. 224, 238 (1988).

123. In re NVIDIA Corp. Sec. Litig., 768 F.3d 1046, 1055 (9th Cir. 2014); see Basic, 485 U.S. at 224 .

124. In re NVIDIA, 768 F.3d at 1054.

125. Stratte-McClure, 776 F.3d at 103.

126. Id. (emphasis in original).

127. See In re NVIDIA, 768 F.3d 1046; Stratte-McClure, 776 F.3d at 94.

128. Brief of Institutional Investors as Amici Curiae in Support of Respondents at 5, Leidos, Inc. v. Ind. Pub. Ret. Sys., 137 S. Ct. 1395 (2017) (No. 16-581) [hereinafter II Brief] (quoting Bateman Eichler, Hill Richards, Inc. v. Berner, 472 U.S. 299, 310 (1985)).

129. Stoneridge Inv. Partners, LLC v. Scientific-Atlanta, Inc., 552 U.S. 148, 174 n.10 (2008) (quoting S. REP. No. 104-98, at 8 (1995)). 
losses' - a matter crucial to the integrity of domestic capital markets." 130

1. The SEC's Stance on Item 303.- The SEC has insisted that a violation of Item 303 or any other disclosure obligation can be the basis for a claim under Rule 10b-5. ${ }^{131}$ The SEC has conducted proceedings and imposed sanctions based on omissions from an MD\&A which contravened Item 303. ${ }^{132}$ In In re Cypress Bioscience Inc., the SEC found a Rule 10b-5 violation in which a Form 10-Q had false financial statements and "failed to disclose" information in the MD\&A. ${ }^{133}$ In In re Fitzpatrick, the SEC found that "information omitted from First Capital Holdings' 1990 Form 10-K was clearly material," and that the defendants "knew or were reckless in not knowing of the disclosure failures." ${ }^{\prime 34}$

Furthermore, the SEC has maintained an identical position in administrative proceedings.$^{135}$ In In re Ciro, Inc., the SEC ruled that an issuer violated Rule 10b5 by submitting multiple Forms $10-\mathrm{K}$ that "failed to disclose that [company executive] had filed for personal bankruptcy . . . , as required by Item 401(f) of Regulation S-K." 136 While this is not an Item 303 violation, this example illustrates the SEC's posture of finding that an omission violates Items within Regulation S-K. ${ }^{137}$ In addition, the SEC has long maintained this same position in federal court. ${ }^{138}$ In numerous amicus briefs, the SEC has argued that Item 303 can be the basis for an action based on Rule 10b-5, which enforces a duty to disclose. ${ }^{139}$

Finally, the SEC has announced regulations which agree with the same position that a violation of Item 303 or similar regulations can be the basis for a claim under Rule 10b-5. ${ }^{140}$ As an example, Regulation FD requires that an issuer's disclosure of material non-public information be made to all investors simultaneously when the disclosure is intentional and promptly when it is unintentional. ${ }^{141}$ In the safe harbor provision for this regulation, the SEC provided that "[n]o failure to make a public disclosure required solely by $\S 243.100$ shall

130. Tellabs, Inc. v. Makor Issues \& Rights, Ltd., 551 U.S. 308, 320 n.4 (2007) (quoting Merrill Lynch, Pierce, Fenner \& Smith Inc. v. Dabit, 547 U.S. 71, 81 (2006)).

131. Brief for the United States as Amicus Curiae Supporting Respondents at 13, Leidos, Inc. v. Ind. Pub. Ret. Sys., 137 S. Ct. 1395 (2017) (No. 16-581) [hereinafter U.S. Brief].

132. Id. at 22 .

133. Cypress Bioscience Inc., Securities Act Release No. 7333, Exchange Act Release No. 37701, 1996 WL 531656, at*7 (Sept. 19, 1996); U.S. Brief, supra note 131, at 22.

134. Fitzpatrick, Exchange Act Release No. 34865, 1994 WL 575965, at *6 (Oct. 20, 1994); U.S. Brief, supra note 131, at 22.

135. U.S. Brief, supra note 131, at 22.

136. Ciro Inc., Exchange Act Release No. 34767, 1994 WL 548994, at *5 (Sept. 30, 1994); U.S. Brief, supra note 131, at 22-23.

137. See U.S. Brief, supra note 131, at 21-23.

138. Id. at 23 .

139. Id.

140. Id. at 24 .

141. 17 C.F.R. $§ 243.100$ (a) (2020). 
be deemed to be a violation of Rule 10b-5." ${ }^{142}$ Therefore, without the safe harbor, Regulation FD creates a disclosure duty. ${ }^{143}$ The SEC has imposed similar safe harbor provisions which illustrate that disclosure requirements create a duty to disclose. ${ }^{144}$

2. Half-Truth and Omissions.-In Universal Health Services, Inc. v. United States, the Supreme Court held that "half-truths-representations that state the truth only so far as it goes, while omitting critical qualifying information - can be actionable misrepresentations." 145 The Supreme Court highlighted that an "example of an actionable half-truth in contract law is the seller who reveals that there may be two new roads near a property he is selling, but fails to disclose that a third potential road might bisect the property." ${ }^{\prime 46}$ Whereas in Leidos, the United States Brief noted that " $[\mathrm{t}]$ he Court thus recognized that the disclosure of certain information is often reasonably understood as an implicit representation that no additional risks or obstacles of the same general sort exist." 147 Even though this is a contract principle, there is no reason it should not apply in a securities context where natural inferences occur regularly. ${ }^{148}$

Rule 10b-5 reaches half-truths as the failure "to state a material fact necessary in order to make the statements made, in the light of the circumstances under which they were made, not misleading." "149 Leidos made "statements" by filing a Form 10-K, and "further disclosure was 'necessary' to make those statements 'not misleading' 'in light of the circumstances."'150

In addition to half-truths, Rule 10b-5 asserts that a statement must be "misleading" in order to violate the rule. ${ }^{151}$ "[W] hether a statement is "misleading' depends on the perspective of a reasonable investor[; t]he inquiry . . . is objective." ${ }^{152}$ The United States Brief illustrates that when an issuer submits a filing which is apparently in compliance with the Exchange Act and regulations such as Rule 10b-5, "the nature and scope of those obligations will affect the inferences that a reasonable investor draws from the filing." 153 A reasonable investor is aware that corporations are required to file forms such as Form 10-K, which includes an MD\&A because of SEC regulations. ${ }^{154}$ With this knowledge, an MD\&A becomes misleading when it does not include all information absent

142. 17 C.F.R. $\S 243.102$.

143. See U.S. Brief, supra note 131, at 24.

144. See 17 C.F.R. $§ 240.13 a-11(c)$; U.S. Brief, supra note 131, at 24.

145. Universal Health Servs., Inc. v. United States, 136 S. Ct. 1989, 2000 (2016).

146. Id. (citing Junius Constr. Co. v. Cohen, 178 N.E. 672, 674 (N.Y. 1931)).

147. U.S. Brief, supra note 131, at 14.

148. Id.

149. 17 C.F.R. $\S 240.10 b-5(b)$; U.S. Brief, supra note 131, at 9.

150. U.S. Brief, supra note 131, at 9 (quoting 17 C.F.R. $\S 240.10 b-5(b)$ ).

151. See 17 C.F.R. $\S 240.10 b-5(b)$.

152. Omnicare, Inc. v. Laborers Dist. Council Constr. Indus. Pension Fund, 575 U.S. 175, 18687 (2015).

153. U.S. Brief, supra note 131, at 10 (citation omitted).

154. Id. 
a disclaimer. ${ }^{155}$ In support of this assertion, Item 303 requires the disclosure of all known trends and uncertainties which management has a reasonable expectation of occurring, and not just those which do not hurt the organization. ${ }^{156} \mathrm{~A}$ commenter states, "[T]he reader of the disclosure sees that the issuer is responding to the disclosure obligation and is entitled to assume that the response is not only accurate but complete as well." 157

Unlike many of the SEC required disclosures, Item 303 does not establish a bright-line rule. ${ }^{158}$ Item 303 requires the disclosure of any known trends or uncertainties which are "reasonably likely to result in the registrant's liquidity increasing or decreasing in any material way," 159 or the registrant reasonably expects will "have a material favorable or unfavorable impact on net sales or revenues or income." 160 Therefore, management will sometimes need to determine whether the known trend or uncertainty fulfills the "reasonably likely to have material effect" standard. ${ }^{161}$ As a result, whether disclosure is required or whether an omission is misleading can be unclear from the perspective of the issuer. ${ }^{162}$ In cases in which an omission is misleading, plaintiffs are uncertain whether to plead Item 303's disclosures due to not knowing whether the information was withheld with scienter as opposed to a good-faith assessment. ${ }^{163}$

3. Impact on Investors. - Institutional investors, including pension funds, play an important role in the private enforcement of securities law. ${ }^{164}$ INPRS is an institutional investor with institutional investment funds of millions of active and retired members which maintain billions of dollars in capital. ${ }^{165}$ Much of this capital is invested in the United States capital markets. ${ }^{166}$ These funds have a long-term outlook and have investments in many, if not all, large corporations and, as a result, are opposed to meritless litigation. ${ }^{167}$ Therefore, the investment funds are seeking that "investors not be harmed by the illegal conduct of those who issue and sell publicly traded securities."168 Many state and local governments have retirement or pension funds (INPRS included). As a result, if

155. Id.

156. Id.

157. Donald C. Langevoort \& G. Mitu Gulati, The Muddled Duty to Disclose Under Rule 10b5, 57 VAND. L. REV. 1639, 1680 (2004).

158. U.S. Brief, supra note 131, at 12.

159. 17 C.F.R. $\S 229.303$ (b)(1) (2020).

160. 17 C.F.R. $\$ 229.303($ b)(2)(ii).

161. See Thomas Lee Hazen, Treatise on the Law of Securities Regulation $\S 9: 50$ (7th ed. 2016); U.S. Brief, supra note 131, at 12.

162. U.S. Brief, supra note 131, at 13.

163. Id.

164. II Brief, supra note 128 , at 6 .

165. Id.

166. Id.

167. Id.

168. Id. 
these funds suffered losses due to corporate fraud or other similar behavior, the taxpayer would be caught in a bad situation, as taxpayers would need to replenish these retirement or pension funds. ${ }^{169}$

The MD\&A is frequently one of the most-read portions of reports or forms supplied by publicly traded companies. ${ }^{170}$ Unlike many of the sections of common forms, the MD\&A disclosures are not minor nor technical; they are an investor's chance to understand what a company's management believes are the principal risks and challenges facing the organization. ${ }^{171}$ An MD\&A must contain all of the information required by Item 303 because a reasonable investor would read the MD\&A expecting it to contain all required information. ${ }^{172}$ An MD\&A without all of the requirements of Item 303 would therefore be misleading, which may lead to legal liability. ${ }^{173}$

Institutional investors find Item 303 disclosures to be invaluable to their investment decisions as they "enable[] investors to see the company through the eyes of management." ${ }^{174}$ And these disclosures are forward-looking as opposed to a retrospective view. ${ }^{175}$ Even the SEC has recognized the importance of Item 303 , noting in one of its rule interpretations that the disclosure of known trends or uncertainties is "[o]ne of the most important elements necessary to an understanding of a company's performance, and the extent to which reported financial information is indicative of future results." ${ }^{\text {"176 }}$ Information about known trends or uncertainties is far more important than boilerplate language. ${ }^{177}$ Past factual information is likely already available before a Form is public, whereas the MD\&A "provides unusually valuable insight into how management understands the risks that the company faces." 178 This insight provides investors a look into a company "as seen through the eyes of those who manage that business." $" 179$

In the case of Leidos, the Item 303 information omitted many of the important facts that investors would have wanted to know. ${ }^{180}$ Leidos personnel

169. Id. at 7 .

170. Id. at 9 .

171. Id.

172. U.S. Brief, supra note 131 , at 8 .

173. Id.

174. Commission Guidance Regarding Management's Discussion and Analysis of Financial Condition and Results of Operations, Securities Act Release No. 8350, Exchange Act Release No. 48,960, 68 Fed. Reg. 75,056, 75,056 (Dec. 29, 2003).

175. II Brief, supra note 128, at 10.

176. Commission Guidance Regarding Management's Discussion and Analysis of Financial Condition and Results of Operations, 68 Fed. Reg. at 75,061.

177. II Brief, supra note 128 , at 10.

178. Id. at 11 .

179. Commission Guidance Regarding Management's Discussion and Analysis of Financial Condition and Results of Operations, 68 Fed. Reg. at 75,056.

180. II Brief, supra note 128, at 11. 
were implicated in the multi-million-dollar fraudulent CityTime scheme. ${ }^{181}$ Leidos submitted its Form 10-K on March 25, 2011. ${ }^{182}$ At this time, Leidos was aware that New York City denied Leidos a contract because of the CityTime fraud, the company had hired a law firm to conduct an internal investigation, Leidos had received grand jury subpoenas, and multiple indictments had been issued for several of its high-level officers. ${ }^{183}$ None of this information, including the CityTime fraud scandal, could be found in the March 2011 Form 10-K. ${ }^{184}$ "[A] potential legal liability is an entirely appropriate subject for disclosure under Item $303 \ldots . . .185$

Private enforcement of Item 303's duty to disclose would not cause companies to enforce unnecessary and trivial information. ${ }^{186}$ This position is supported by the Supreme Court which states, "[A] 'fundamental purpose' of the various securities acts, "was to substitute a philosophy of full disclosure for the philosophy of caveat emptor and thus to achieve a high standard of business ethics in the securities industry." "187 Many of those evaluating this type of information are sophisticated and able to ascertain the importance of Item 303 disclosures. ${ }^{188}$ Events that have the potential to cause long-term damage to an organization's business, finances, or reputation are vital to the decision-making of investors. ${ }^{189}$ "These . . . events - things with potential for boom or bust-are exactly the news on which sophisticated investors make most decisions; 'old' news, with settled value, already is reflected in the price of the stock and so is no news at all." ${ }^{.190}$ Investors are entitled to disclosure of the information required by Item $303 .{ }^{191}$

\section{B. Argument for Petitioner}

In order to understand the complete picture, the arguments of the petitioner, Leidos, Inc., need to be highlighted.

1. Item 303 Disclosure Should Not Give Rise to an Actionable Duty Under Rule 10b-5.- Item 303 is not an appropriate source for private actions and private enforcement because it is unclear and difficult to apply. ${ }^{192}$ Item 303 is intended

181. Ind. Pub. Ret. Sys. v. SAIC, Inc., 818 F.3d 85, 89 (2d Cir. 2016).

182. Id.

183. Id. at 89-90.

184. II Brief, supra note 128, at 12.

185. Id.

186. Id. at 13 .

187. Basic Inc. v. Levinson, 485 U.S. 224, 234 (1988) (quoting SEC v. Capital Gains Research Bureau, Inc., 375 U.S. 180, 186 (1963)).

188. II Brief, supra note 128 , at 13.

189. Id.

190. Flamm v. Eberstadt, 814 F.2d 1169, 1175 (7th Cir. 1987).

191. II Brief, supra note 128 , at 14 .

192. Brief for the Securities Industry and Financial Markets Association and the Chamber of 
for company managers to use their best judgment in disclosing known trends and uncertainties. ${ }^{193}$ Even though the SEC has attempted to provide abundant guidance on the matter, management is still uncertain about what needs to be included in an MD\&A pursuant to Item $303 .{ }^{194}$ Furthermore, the SEC discourages companies from including information that is considered not required and not helpful. ${ }^{195}$

The SEC believed that forward-looking information was too untrustworthy to disclose before the creation of Item 303. ${ }^{196}$ In the past, "the Commission's approach to MD\&A was to discourage predictive statements and to focus primarily on historical information, on the theory that although soft information was inherently unreliable, the public might give it undue credence." 197 At one point, the SEC considered predictive information to be "misleading within the meaning of this rule: ... [p]redictions as to specific future market values, earnings, or dividends." ${ }^{198}$ Multiple courts also held this point of view. ${ }^{199}$ In Rodman v. Grant Foundation, the Second Circuit held, "Full factual disclosure need not be embellished with speculative financial predictions." ${ }^{200}$ In Union Pacific Railroad Co. v. Chicago and North Western Railway Co., the court stated that "prediction[s] of specific earnings" were "extremely speculative" and "possibly misleading." 201 And in Arber v. Essex Wire Corp., the Sixth Circuit noted that "the law mandates disclosure only of existing material facts. It does not require an insider to volunteer any economic forecast." 202

Item 303 formulates two different types of forward-looking information: required and optional. ${ }^{203}$ In the context of Item 303, required information includes material and known trends, events, and uncertainties. ${ }^{204}$ Optional information includes the disclosure of anticipation of a future event, trend, or uncertainty. ${ }^{205}$ As the Brief for the Securities Industry and Financial Markets Association and the Chamber of Commerce of the U.S. points out, the line between required and optional disclosure was "blurry at best," and the SEC seemed to acknowledge this

Commerce of the United States of America as Amici Curiae Supporting Petitioner at 5, Leidos, Inc. v. Ind. Pub. Ret. Sys., 137 S. Ct. 1395 (2017) (No. 16-581) [hereinafter SI, FMA, and CoC Brief].

193. Id.

194. Id.

195. Id. at 6 .

196. Id.

197. Mark S. Croft, MD\&A: The Tightrope of Disclosure, 45 S.C. L. REV. 477, 483 (1994) (citations omitted).

198. SI, FMA, and CoC Brief, supra note 192, at 6 (citation omitted).

199. Id. at 6-7.

200. Rodman v. Grant Found., 608 F.2d 64, 72 (2d Cir. 1979) (citation omitted).

201. Union Pac. R.R. v. Chi. \& N.W. Ry. Co., 226 F. Supp. 400, 409-10 (N.D. Ill. 1964).

202. Arber v. Essex Wire Corp., 490 F.2d 414, 421 (6th Cir. 1974).

203. SI, FMA, and CoC Brief, supra note 192, at 9.

204. Id.

205. Id. 
point. ${ }^{206}$ In addition to plain language of Item 303 being confusing, the guidance on how to comply with Item 303 was puzzling. ${ }^{207}$ At one point, the guidance indicated that "[r] egistrants are encouraged, but not required, to supply forwardlooking information." ${ }^{208}$ However in the subsequent sentence, the guidance indicated that "presently known data which will impact upon future operating results ... may need to be disclosed." 209 The guidance provided very few examples and did not provide a meaningful test for determining when information would not be forward-looking but also have an impact upon future operating results. ${ }^{210}$

Even though the SEC has made several efforts to clarify the disclosure provisions of Item 303, management is still uncertain when a predictive known trend or event goes from optional disclosure to mandatory. ${ }^{211}$ Commenters have stated: "the test set out by the Commission for assessing MD\&A disclosures has been poorly worded and incongruous for twenty-six years," 12 and "the distinction that the SEC has drawn between required and optional disclosures is so subtle that corporations and courts alike find Item 303 of Regulation S-K difficult to apply." 213 Item 303 provides management significant deference in what to disclose in MD\&As. ${ }^{214}$ The SEC has recognized that "if its disclosure regime were both hard to apply and hard on managers who misapplied it, managers would have to protect themselves through prophylactic over-disclosure." 215 In fact, the SEC has insisted on the subjective nature of deciding what needs to be disclosed. ${ }^{216}$ Item 303 narratives should allow "investors to see the company through the eyes of management," ${ }^{217}$ as " $[\mathrm{m}]$ anagement has a unique perspective on its business that only it can present." 218

2. Adverse Effects on Industry with No Benefit to Investors.-There would be numerous unintended consequences if a material omission within Item 303 leads to liability in a suit by a private plaintiff. ${ }^{219}$ Because of this change, there would

206. $I d$.

207. Id.

208. Id. at 9-10 (quoting 17 C.F.R. $§ 229.303 \mathrm{cmt} .7$ (1993)).

209. Id. at 10 (quoting 17 C.F.R. $\S 229.303 \mathrm{cmt} .7$ ).

210. Id.

211. Id.

212. Crawford \& Galaro, supra note 12 , at 1.

213. Suzanne J. Romajas, The Duty to Disclose Forward-Looking Information: A Look at the Future of MD\&A, 61 FordHAM L. REV. S245, S286 (1993).

214. SI, FMA, and CoC Brief, supra note 192, at 11.

215. Id.

216. Commission Guidance Regarding Management's Discussion and Analysis of Financial Condition and Results of Operations, Securities Act Release No. 8350, Exchange Act Release No. 48,960, 68 Fed. Reg. 75,056, 75,057 (Dec. 29, 2003).

217. Id. at 75,058 .

218. Id.

219. Brief of Amicus Curiae Retail Litigation Center, Inc. in Support of Petitioner at 19, 
be uncertainty between what is fraud and what is mistake, within the economic market, and in how to properly comply with Item $303 .{ }^{220}$ In addition, private plaintiffs may be incentivized to engage in bad-faith litigation and may even harm the interests of the investors that should be protected by this change. ${ }^{221}$

Private parties will use the duty to disclose under Item 303 in order to "use the securities laws as a form of hindsight insurance and create a headwind against economic growth by adding to companies' administrative burdens." ${ }^{222}$ The "practical consequences" of this change could potentially lead to serious issues in the market. ${ }^{223}$

Item 303 disclosures present issues of timing. ${ }^{224}$ Information that is found to be material will have been known to management before it is disclosed in any Form or an MD\&A. ${ }^{225}$ The Second Circuit's approach exposes corporations to "allegations of fraud by hindsight." 226 The argument is made for the plaintiff if the known trend or event had a material impact. ${ }^{227}$ Companies will be subject to fraud claims for failing to disclose a certain event at a time when it was only a mere possibility. ${ }^{228}$ Hindsight bias will play a factor in any determination where Item 303 is involved. ${ }^{229}$ "In the context of securities regulation, hindsight can mistakenly lead people to conclude that a bad outcome was not only predictable, but was actually predicted by managers." ${ }^{230}$

The Retail Litigation Center, Inc. Brief notes that certain industries, such as the retail industry, are particularly vulnerable to this type of litigation. ${ }^{231}$ Private plaintiffs will be able to "seize[] upon disclosures made in later annual reports and allege[] that they should have been made in earlier ones." ${ }^{.32}$

To avoid litigation, managers will be incentivized to circumvent liability by over-reporting and disclosing irrelevant occurrences which could possibly become any material, known trend. ${ }^{233}$ Many contacts with government agencies, such as those involving citations or small fines, are not visible to management and are never disclosed as Item 303 events. ${ }^{234}$ The cost of compliance to make

Leidos, Inc. v. Ind. Pub. Ret. Sys., 137 S. Ct. 1395 (2017) (No. 16-581) [hereinafter RLC Brief].

220. Id.

221. Id.

222. Id.

223. Id. (citing Stoneridge Inv. Partners, LLC v. Scientific-Atlanta, Inc., 552 U.S. 148, 157-64

(2008)).

224. Id. at 20.

225. Id.

226. Id. (quoting Tellabs, Inc. v. Makor Issues \& Rights, Ltd. 551 U.S. 308, 320 (2007)).

227. $I d$.

228. Id.

229. Id. at 21.

230. Mitu Gulati et al., Fraud by Hindsight, 98 Nw. U. L. REv. 773, 774 (2004).

231. RLC Brief, supra note 219, at 21.

232. Id. (quoting Denny v. Barber, 576 F.2d 465, 470 (2d. Cir. 1978)).

233. Id. at 22 .

234. Id. 
sure everything is disclosed properly will be significant. ${ }^{235}$ For example, in 2004, the SEC added to its Form 8-K requirements that cost the market \$22.1 million per year because companies were required to further clarify disclosures and make more disclosures. ${ }^{236}$

3. A Private Right of Action Would Dramatically Alter the Disclosure Process. - The extension of Item 303 liability to private plaintiffs would lead to disclosures being less useful to investors, and more expensive for issuers to prepare. ${ }^{237}$ This change will alter the disclosure process and possibly lead to disclosures which are less helpful to investors. ${ }^{238}$ It can be a struggle for management to determine what is a trend or uncertainty that may materially affect a business, and difficult judgments must be made in determining what should be disclosed under the ambiguous Item 303. ${ }^{239}$ The SEC has acknowledged the difficulty of identifying trends, noting "even the most carefully prepared and thoroughly documented projections may prove inaccurate." ${ }^{240}$ To avoid liability and costly litigation, companies will over-disclose. ${ }^{241}$ This line of thinking could possibly lead to "double negative" disclosure where "if management cannot conclude that a trend is unlikely to materialize, then it must disclose unless management determines that the trend would be immaterial"; this double negative disclosure only enhances the burden on corporate management. ${ }^{242}$

Management would also be more likely to make premature disclosures, which carry their own risks. ${ }^{243}$ A premature disclosure could lead investors to believe an issuer is in danger (when it really is not), which would lead to a decrease in price per share and market capitalization. ${ }^{244}$ A premature disclosure is also likely to be less thought out or complete while the issuer waits to see if the event is actually a known trend or uncertainty. ${ }^{245}$ The result is a disclosure system where there are more lower-quality disclosures. ${ }^{246}$

The increased disclosure of unhelpful information will hurt investors. ${ }^{247}$ This information is not only unhelpful, but it also adds to an already voluminous

235. Id. at 25 .

236. Id.

237. Brief for the Society for Corporate Governance as Amicus Curiae Supporting Petitioner at 18, Leidos, Inc. v. Ind. Pub. Ret. Sys., 137 S. Ct. 1395 (2017) (No. 16-581) [hereinafter SCG Brief].

238. Id.

239. Id.

240. Id. at 19 (quoting Safe Harbor Rule for Projections; Final Rule, Securities Act Release No. 6084, Exchange Act Release No. 15,944, 44 Fed. Reg. 38,810, 38,810 (July 2, 1979)).

241. Id. at 20.

242. Id.

243. Id. at 21 .

244. Id.

245. Id.

246. Id. at 22 .

247. Id. at 23 . 
disclosure. ${ }^{248}$ In 2013, the average length of public companies' annual SEC filings on Form $10-\mathrm{K}$ was already almost 42,000 words, nearly three times the length permitted for a merits brief in federal court and longer than a short book. ${ }^{249}$ This growing flood of trend disclosures will hurt investors' understanding of which trends management actually considers to be relevant and not just the trends that management discloses to avoid hindsight liability. ${ }^{250}$

\section{ANALYSIS ARGUING FOR A PRIVATE RIGHT OF ACTION}

\section{A. Increased Disclosure}

Leidos, the petitioner, quotes the Supreme Court: "Even with respect to information that a reasonable investor might consider material, companies can control what they have to disclose under [Rule 10b-5] by controlling what they say to the market." ${ }^{\text {"251 }}$ Leidos argues this changes the rule so that silence is not misleading even when under a duty to disclose. ${ }^{252}$ However, Rule $10 \mathrm{~b}-5$ requires an affirmative duty to disclose so that "statements made, in the light of the circumstances under which they were made, [are] not misleading." ${ }^{253}$ The Supreme Court then illustrates, "Silence, absent a duty to disclose, is not misleading under Rule 10b-5." 254 The holding from the Supreme Court in Basic is one of the petitioner's fundamental arguments. ${ }^{255}$ The United States Brief asserts, "That argument would lack merit even if petitioner had been silent, because (as alleged here) petitioner breached its disclosure obligations under Item 303." 256 When a disclosure duty occurs, "silence can be misleading because a reasonable investor will be aware of the duty and will reasonably infer from a regulated party's silence that no circumstance for which disclosure is required is actually present." ${ }^{257}$ In this case, Leidos was not silent as it published an MD\&A disclosing various known trends and uncertainties, but made no reference or mention of the CityTime fraud..$^{258}$ In spite of the requirements of Item 303, a

248. Id.

249. See Vipal Monga \& Emily Chasan, The 109,894-Word Annual Report, Wall Street J. (June 2, 2015), https://blogs.wsj.com/cfo/2015/06/02/the-109894-word-annual-report/ [https:// perma.cc/8TKX-GK37].

250. SCG Brief, supra note 237, at 23-24.

251. Brief for Petitioner at 4, Leidos, Inc. v. Ind. Pub. Ret. Sys., 137 S. Ct. 1395 (2017) (No. 16-581) [hereinafter Leidos Brief] (quoting Matrixx Initiatives, Inc. v. Siracusano, 563 U.S. 27, 45 (2011) (alteration in original)).

252. See id.

253. 17 C.F.R. $\S 240.10 b-5$ (b) (2020).

254. Basic Inc. v. Levinson, 485 U.S. 224, 239 n.17 (1988).

255. See U.S. Brief, supra note 131, at 8 .

256. $I d$.

257. Id. at 15 (emphasis omitted).

258. Id. at 8 . 
Form 10-K was filed in March 2011.259

Disclosure requirements are in effect for the benefit of investors to ensure that issuers disclose information which is pertinent to investing. ${ }^{260}$ Investors' decisions are affected even when there is no actual disclosure because investors will infer that events where disclosure was required did not occur. ${ }^{261}$ Silence is viewed differently in this context because disclosures are required under the Securities Act and the Exchange Act, as opposed to an unregulated environment. ${ }^{262}$ If issuers were permitted to make tactical and deliberate omissions, disclosure, which is "designed to protect investors even when there is no fraud, would afford a shelter or sanctuary for those who defraud investors." 263

\section{B. Disarming Leidos's Contentions}

Leidos contends that the MD\&A can only lead to liability under Rule 10b-5 if there is an affirmative false statement or a misrepresentation. ${ }^{264}$ Under this reasoning, a pure omission would not lead to liability. ${ }^{265}$ But as the United States Brief demonstrates, there would be liability if the MD\&A section opened with: "This section discloses all the information required by Item 303." 266 The absence of this statement should not lead to an entirely different result; "a reasonable investor understands the MD\&A section of a Form $10-\mathrm{K}$ to make the same representation implicitly."267

Petitioner argues that an incomplete MD\&A should never give rise to liability under Section 10(b) or Rule 10b-5. ${ }^{268}$ However, if an issuer acts with scienter, the omission should give rise to liability. ${ }^{269}$ To hold otherwise would be inapposite due to the text of Rule 10b-5 and several court precedents, including Basic. ${ }^{270}$

Arguably, this topic is unduly novel, and, therefore, this case should be rejected. ${ }^{271}$ The SEC and the judicial system frequently apply the Securities Act and the Exchange Act to new or novel types of fraudulent schemes. ${ }^{272}$ The Supreme Court has even pointed out as much, stating the Court has "repeatedly

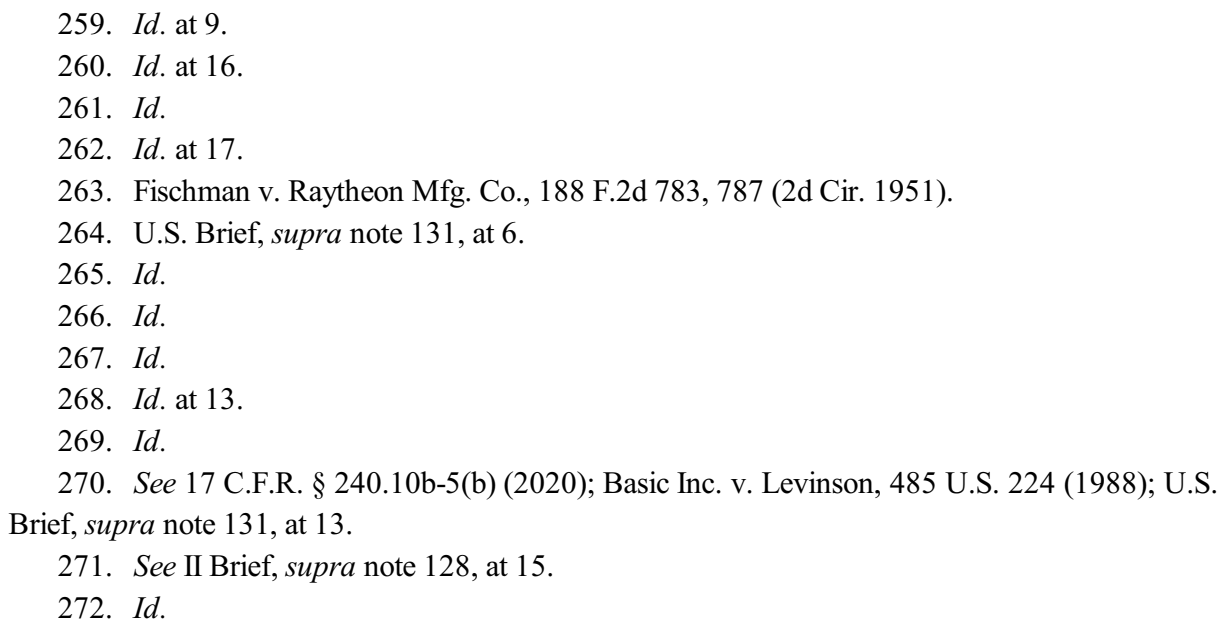


recognized that securities laws combating fraud should be construed 'not technically and restrictively, but flexibly to effectuate [their] remedial purposes." ${ }^{, 273}$ The Supreme Court has also pointed out that the contents of Rule 10b-5 and Section 10(b) 'are broad and, by repeated use of the word 'any,' are obviously meant to be inclusive." 274 The viewpoint that the area is too novel would affect the SEC enforcement in addition to private plaintiffs. ${ }^{275}$ However, Section 10(b) has been "described rightly as a 'catchall' clause to enable the Commission "to deal with new manipulative [or cunning] devices." 276 As a result, the private cause of action under Rule 10b-5 should extend to violations of Item 303.

\section{Item 303 Claims Will Not Be Any Easier to Prove than Any Other Rule 10b-5 Claim}

In the Leidos Brief, an argument is made that the court of appeals' decision does have an effect on private suits that apply Item 303 or Regulation S-K. ${ }^{277}$ Contrarily, the "failure to disclose all of the information Item 303 requires does not violate . . Rule 10b-5." ${ }^{278}$ In a Rule 10b-5 action, both the SEC and private parties must also prove the disclosure (or omission) was in connection with the purchase or sale of a security, was material, and made with scienter. ${ }^{279}$ In addition, private plaintiffs must plead reliance, loss, and "loss causation." 280 As the United States Brief demonstrates, materiality and scienter are "significant requirements." ${ }^{281}$ Importantly, "[a] plaintiff cannot establish materiality under Basic simply by identifying a violation of Item $303 \ldots . .282$ Oran states that Item 303's mandate is "considerably beyond those required by Rule 10b-5."283 In contrast to the requirements of Item 303, Basic requires "a substantial likelihood that the disclosure of the omitted fact would have been viewed by the reasonable investor as having significantly altered the 'total mix' of information made available." 284 As a result, Item 303 information that is not disclosed is not "inevitably" material under the Basic standard. ${ }^{285}$ The difference between these

273. Herman \& MacLean v. Huddleston, 459 U.S. 375, 386-87 (1983) (quoting SEC v. Capital Gains Research Bureau, Inc., 375 U.S. 180, 195 (1963)).

274. Affiliated Ute Citizens of Utah v. United States, 406 U.S. 128, 151 (1972).

275. II Brief, supra note 128 , at 16.

276. Ernst \& Ernst v. Hochfelder, 425 U.S. 185, 202-03 (1976) (citation omitted).

277. Leidos Brief, supra note 251, at 36-38.

278. U.S. Brief, supra note 131, at 24.

279. Id. at 25 .

280. Dura Pharm., Inc. v. Broudo, 544 U.S. 336, 341-42 (2005).

281. U.S. Brief, supra note 131, at 25.

282. Id.

283. Oran v. Stafford, 226 F.3d 275, 288 (3d Cir. 2000).

284. Basic Inc. v. Levinson, 485 U.S. 224, 231-32 (1988) (quoting TSC Indus., Inc. v. Northway, Inc., 426 U.S. 438, 449 (1976)).

285. See Oran, 226 F.3d at 288. 
two standards does not impose a rule in which information required by Item 303 can never be material. ${ }^{286}$ Private plaintiffs must prove that the omission was information required by Item 303 , and that the omission reached the materiality threshold established in Basic. ${ }^{287}$

Returning to scienter, a plaintiff is unable to establish scienter by showing a violation of Item $303 .{ }^{288}$ Plaintiffs find it difficult to show a violation of Item 303, let alone a violation of Item 303 with scienter. The Private Securities Litigation Reform Act grants even further protection in private suits, as private plaintiffs must plead "with particularity facts giving rise to a strong inference that the defendant acted with the required state of mind." ${ }^{289}$ In this case, the district court dismissed most of the Item 303 claims because of the inadequate pleading of the additional elements required by Rule $10 \mathrm{~b}-5$ and Section 10(b). ${ }^{290}$ INPRS acknowledged that "significant hurdles" remained "to pleading and proving a private claim based on an alleged omission of Item 303 information." 291 Therefore, an issuer will not be held liable for a mere violation of Item 303; a private plaintiff must also prove all of the traditional elements in a Section 10(b) cause of action in addition to the elements required in private actions. ${ }^{292}$ In most cases, the plaintiff will need to "prove that [the issuer] defrauded them by omitting material information with scienter, and that they sustained losses as a result." ${ }^{293}$ There is little to no danger in allowing an investor an additional avenue for recovery, as long as the investor proves all of the elements required in a private Rule 10b-5 action.

\section{No Evidence of an Abundance of Item 303 Litigation}

Leidos argues in its brief that numerous cases will be filed if a private right of action is granted under Item $303 .{ }^{294}$ Leidos highlights that "nearly two dozen" cases have been filed in the Second Circuit after the decision in Stratte-McClure, as opposed to only a "handful" in the Ninth Circuit. ${ }^{295}$ At the time of the StratteMcClure decision, the Ninth Circuit had already held that Item 303 could never lead to liability for an issuer. ${ }^{296}$ Therefore, the argument that a private cause of

286. U.S. Brief, supra note 131, at 25.

287. Id.

288. Id. at 26 .

289. 15 U.S.C. $\S 78 \mathrm{u}-4(\mathrm{~b})(2)(\mathrm{A})(2020)$.

290. See In re SAIC, Inc. Sec. Litig., No. 12 Civ. 1353 (DAB), 2014 U.S. Dist. LEXIS 144445 (S.D.N.Y. Sep. 30, 2014).

291. Leidos Brief, supra note 251, at 49 n.6.

292. U.S. Brief, supra note 131, at 26.

293. Id.

294. Leidos Brief, supra note 251, at 47.

295. Id.

296. See In re NVIDIA Corp. Sec. Litig., 768 F.3d 1046, 1056 (9th Cir. 2014). 
action for Item 303 would lead to an increase in overall litigation is unproven. ${ }^{297}$

The Institutional Investors Brief further disarms this argument of a "flood" of "hindsight-driven litigation." ${ }^{298}$ The SEC was enforcing Item 303 disclosure violations under Rule 10b-5 at least since 1987 and the Supreme Court's decision in Basic. $^{299}$ The Third Circuit has allowed private actions in Item 303 enforcement since its decision in Oran in $2000 .{ }^{300}$ If the flood of litigation were to happen, it already would have. ${ }^{301}$

Leidos insists that the circuit court ruling would "undermine the flexibility inherent in the Commission's disclosure regime" and "incentivize registrants to flood the market with immaterial and premature disclosures." 302 However, SEC enforcement of Rule 10b-5 claims established on Item 303 violations shows that enforcement of disclosures of Item 303 benefits the quality of disclosures made. ${ }^{303}$ The Supreme Court in Basic has already addressed the concern of increased litigation, being "careful not to set too low a standard of materiality" due to a "concern[] that a minimal standard might bring an overabundance of information within its reach." 304 The materiality standard applies to all Rule 10b-5 cases, including suits predicated on violations of Item $303 .{ }^{305}$

If the petitioner's position of no private right of action were adopted, investors and securities markets would be harmed. ${ }^{306}$ This approach would allow fraudulent behavior to go unchecked by financially injured investors. ${ }^{307}$ An issuer could intentionally violate Item 303 by omitting a material disclosure in order to trick investors into thinking that the security is not as risky. ${ }^{308}$ This legal theory could potentially extend to other arenas of securities law that could have harmful effects on both the market and the regulatory scheme. ${ }^{309}$ In addition, the United States Brief highlights that this position would lead to the "disparate treatment of materially equivalent conduct." ${ }^{\text {310 }}$

\section{CONCLUSION}

In Stratte-McClure v. Stanley, the Second Circuit became the first circuit to hold that Item 303 of Regulation S-K allows a private right of action under Rule

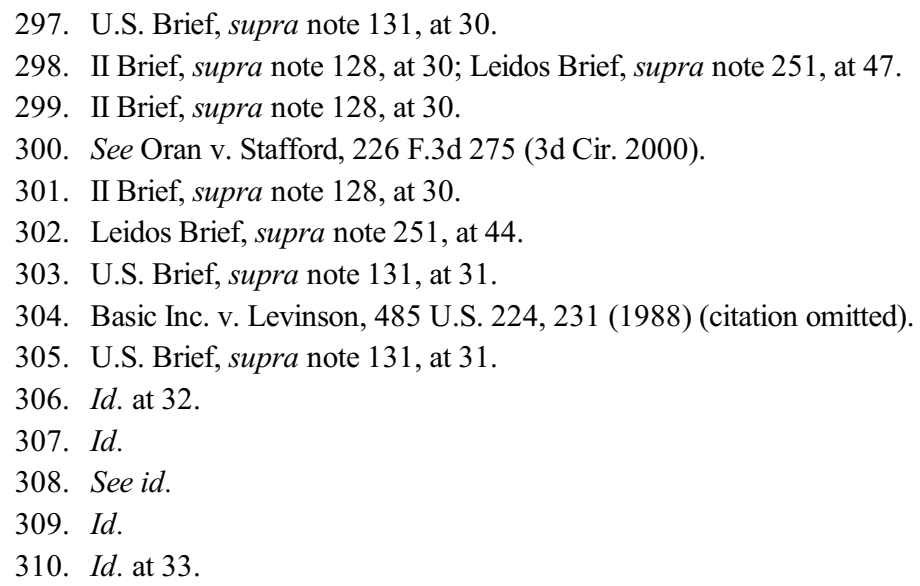


10b-5. ${ }^{311}$ This created a circuit split between the Second Circuit and the Third and Ninth Circuits. The Supreme Court granted certiorari in Leidos, Inc. v. Indiana Public Retirement System in order to settle this circuit split. However, the parties in the case settled right before their case was set to be heard. Now, there is an unsettled issue regarding Item 303 and whether there should be a private right of action.

This Note examined the circuit split and how the circuit courts reached their holdings. Understanding the holdings of the circuit courts is important, as it allows this Note to speculate on the possible consequences of the Supreme Court's decision. This Note argued that Item 303 material misstatements and omissions through Rule 10b-5 should provide a private right of action. The Second Circuit was correct in its holding of both Stratte-McClure v. Stanley and Indiana Public Retirement System v. SAIC, Inc. This conclusion was substantiated by the harm that would be caused by finding that there is no private right of action. The periodic filing system that investors have relied on for decades will be hampered. SEC enforcement of Item 303 nondisclosures has been and will continue to be an insufficient cure to this issue. A private right of action for Item 303 would provide institutional investors, a foundation of the U.S. economy, another means to deter fraudulent or misleading behavior. There will not be an abundance of litigation as plaintiffs in securities class-action lawsuits have a vested interest in the financial health of the corporation-defendant, unlike plaintiffs in most other class-actions.

311. See Stratte-McClure v. Stanley, 776 F.3d 94 (2d Cir. 2015). 